Syntax Literate: Jurnal Ilmiah Indonesia p-ISSN: 2541-0849

e-ISSN: 2548-1398

Vol. 6, No. 10, Oktober 2021

\title{
PERTIMBANGAN HUKUM HAKIM TERHADAP PEMILIKAN DAN PENGEDARAN OBAT KERAS TANPA RESEP DOKTER
}

\section{Stevanus Miharso}

Sekolah Tinggi Ilmu Hukum (STIH) IBLAM Jakarta, Indonesia

Email: stevanusmiharso1@gmail.com

\begin{abstract}
Abstrak
Obat merupakan salah satu unsur penting dalam pelayanan kesehatan yang harus selalu tersedia dan tidak tergantikan pada pelayanan kesehatan. Obat dapat merugikan kesehatan, bila digunakan secara tidak tepat atau bila disalah gunakan. Terkait dengan adanya penggolongan obat maka pemberian obat kepada konsumen ada aturan-aturan yang harus diterapkan. Seperti kasus pelanggaran atas pemilikan dan pengedaran obat keras yang dilakukan tanpa resep dokter dan telah diputus oleh Pengadilan dengan putusan Nomor: 59/Pid.Sus/2018/PN.Cbi, dan pelakunya diganjar dengan hukuman penjara selama 1 (satu) tahun dan 4 (empat) bulan dan denda sejumlah Rp. 10.000.000 (sepuluh juta rupiah). Adapun metode penelitian yang penulis gunakan adalah metode yuridis normatif yaitu menganalisis kaitan antara peraturan perundang-undangan yang berlaku dengan teori-teori hukum dan praktek pelaksanaan hukum positif yang menyangkut permasalahan yang dibahas. Akhirnya penulis menyimpulkan bahwa Tanggungjawab hukum terhadap pengedaran obat keras tanpa resep dokter, dapat dijerat dengan Pasal 196 UndangUndang Nomor 36 Tahun 2009 tentang Kesehatan, bahwa : Setiap orang yang dengan sengaja memproduksi atau mengedarkan sediaan farmasi dan/atau alat kesehatan yang tidak memenuhi standar dan/atau persyaratan keamanan, khasiat atau kemanfaatan, dan mutu sebagaimana dimaksud dalam Pasal 98 ayat (2) dipidana dengan pidana penjara paling lama 10 (sepuluh) tahun dan denda paling banyak Rp1.000.000.000,00 (satu miliar rupiah). Namun dalam Putusan Pengadilan Nomor: 59/Pid.Sus/2018/PN.Cbi terdakwa Zainal Abidin Bin Basyah (Alm) oleh karena itu dengan pidana penjara selama 1 (satu) tahun dan 4 (empat) bulan dan denda sejumlah Rp. 10.000.000 (sepuluh juta rupiah).
\end{abstract}

Kata Kunci: putusan hakim; obat keras; kasus hukum

\section{Abstract:}

Medicine is one of the important elements in health services that must always be available and irreplaceable in health services. Drugs can be detrimental to health, when used inappropriately or if misused. Related to the classification of drugs, the provision of drugs to consumers there are rules that must be applied. Such as the case of violations of the possession and distribution of hard drugs carried out without a doctor's prescription and has been decided by the Court by decision Number: 59 / Pid.Sus / 2018 / PN. Cbi, and the culprit were rewarded with imprisonment for 1 (one) year and 4 (four) months and a fine of Rp. 10,000,000

$\begin{array}{ll}\text { How to cite: } & \text { Miharso. S (2021) Pertimbangan Hukum Hakim Terhadap Pemilikan dan Pengedaran Obat Keras Tanpa Resep } \\ & \text { Dokter. Syntax Literate: Jurnal Ilmiah Indonesia, 6(10). http://dx.doi.org/10.36418/ Syntax- } \\ & \text { Literate.v6i10.4374 } \\ & \text { 2548-1398 } \\ \text { E-ISSN: } & \text { Ridwan Institute }\end{array}$


(ten million rupiah). The research method that the author uses is a normative juridical method that analyzes the relationship between applicable laws and regulations and the practice of positive legal implementation that concerns the issues discussed. Finally, the author concludes that the legal responsibility for the distribution of hard drugs without a prescription, can be ensnared by Article 196 of Law No. 36 of 2009 on Health, that: Any person who intentionally produces or distributes pharmaceutical preparations and / or medical devices that do not meet the standards and / or requirements of safety, efficacy or benefit, and quality as referred to in Article 98 paragraph (2) is punished with a maximum prison sentence of 10 (ten) know $n$ and a maximum fine of Rp1,000,000,000.00 (one billion rupiah). But in court decision Number: 59/Pid.Sus/2018/PN. Cbi defendant Zainal Abidin Bin Basyah (Alm) therefore with imprisonment for 1 (one) year and 4 (four) months and a fine of Rp. 10,000,000 (ten million rupiah).

Keywords: the judge's decision; hard drugs; legal case

Received: 2021-09-20; Accepted: 2021-10-05; Published: 2021-10-20

\section{Pendahuluan}

Kesehatan merupakan hak asasi manusia. Setiap orang mempunyai hak untuk hidup layak, termasuk didalamnya mendapatkan kesehatan yang baik. Kemajuan ilmu pengetahuan dan teknologi mendorong masyarakat untuk memperhatikan derajat kesehatan demi menaikkan kualitas hidupnya. Obat merupakan salah satu unsur penting dalam pelayanan kesehatan yang harus selalu tersedia dan tidak tergantikan pada pelayanan Kesehatan (Meitasari, 2017). Secara umum pengertian Obat adalah suatu bahan yang dimaksudkan untuk digunakan dalam menetapkan diagnosa, mencegah, mengurangkan, menghilangkan, menyembuhkan penyakit atau gejala penyakit,luka atau kelainan badaniah dan rohaniah pada manusia atau hewan, memperelok badan atau bagian badan manusia (Anief, 1997). Namun di sisi lain, obat dapat merugikan kesehatan bila tidak memenuhi persyaratan, bila digunakan secara tidak tepat atau bila disalahgunakan. Ketepatan penggunaan ini menjadi aspek penting dalam penggunaan obat karena ketidaktepatan penggunaan obat dapat menyebabkan banyak kerugian, baik itu kerugian dari sisi finansial maupun kerugian bagi Kesehatan. BPOM awal nya dibentuk oleh organisasi apoteker dan hingga tahun 2000 masih berada dibawah Departemen Kesehatan sedang melalui Keputusan Presiden No. 103 Tahun 2000 mengalami perubahan dan akhir nya melalui Keputusan Presiden No. 166 Tahun 2003 menjadi sebuah lembaga pemerintah non departemen dibawah presiden langsung yang bertugas mengawasi peredaran obat dan makanan dengan skala nasional. Apoteker sendiri mempunyai arti menurut pasal 1 angka 5 Undang-Undang Nomor 51 Tahun 2009 tentang Pekerjaan Kefarmasian "Apoteker adalah sarjana farmasi yang telah lulus sebagai Apoteker dan telah mengucapkan sumpah jabatan Apoteker" (Oh, 2016).

Menurut Badan Pengawas Obat dan Makanan (BPOM), ada dua golongan obat yang dipasarkan, yakni: 
1. Obat yang diperoleh tanpa resep dokter, yaitu obat bebas dan obat bebas terbatas atau dikenal dengan sebutan Over The Counter (OTC). Obat bebas maksudnya obat yang dapat diperoleh dari toko obat, pedagang eceran obat berizin yang dipimpin oleh asisten apoteker dan dari apotek. Golongan obat ini ditandai dengan lingkaran bulat berwarna hijau dengan garis tepi warna hitam (Anief, 1997).

2. Obat yang hanya dapat diperoleh dengan resep dokter (Ethical) dan dibeli di apotek, dengan tanda khusus yaitu lingkaran yang berwarna merah dan bergaris tepi berwarna hitam dengan huruf $\mathrm{K}$ warna hitam yang menyentuh garis tepi dalam lingkaran tersebut. Adapun obat ethical ini terdiri dari :

a. Daftar $\mathrm{G}$ atau obat keras adalah golongan obat-obat antibiotika, anti diabetes, anti histamin dan lainnya;

b. Daftar $\mathrm{O}$ atau obat bius adalah golongan obat-obat narkotika.

c. Obat Keras Tertentu (OKT) atau psikotropika, seperti obat penenang, obat sakit jiwa, obat tidur, dan lainnya.

d. Obat wajib apotek yaitu obat keras yang dapat dibeli dengan resep Dokter, namun dapat pula diserahkan oleh apoteker kepada pasien di apotek tanpa resep dokter dengan jumlah tertentu, seperti anti histamin, obat asma, pil anti hamil, beberapa obat kulit tertentu dan lainnya (DepKes, 2006).

Terkait dengan adanya penggolongan obat tersebut dan bagaimana aturan yang seharusnya dalam memperolehnya, maka tentu saja ada jalur resmi dan proses penjualan yang harus dilalui oleh pelaku usaha dalam memperdagangkan atau mendistribusikan jenis obat kepada masyarakat, khususnya terhadap konsumen. Konsumen menjadi sasaran aktivitas bisnis untuk meraup keuntungan yang sebesar-besarnya oleh pelaku usaha melalui kiat promosi, cara penjualan, serta penerapan perjanjian standar yang terkadang merugikan konsumen. Faktor utama yang menjadi kelemahan konsumen, adalah tingkat kesadaran konsumen akan hak nya masih rendah (Atmoko \& Kurniawati, 2009).

Undang Undang Kesehatan pertama kali di Indonesia diundangkan yaitu No. 23 Tahun 1992 dan telah direvisi menjadi No. 36 Tahun 2009 dikarenakan sudah tidak relevan lagi. Sebagai pelaksana dari Undang Undang Kesehatan dikeluarkanlah salah satunya yaitu Peraturan Pemerintah Nomor 51 Tahun 2009 tentang Pekerjaan Kefarmasian mengatur Pekerjaan Kefarmasian dalam pengadaan, produksi, distribusi atau penyaluran, dan pelayanan sediaan farmasi (Indonesia, 2009). Yang dimaksud dengan sediaan Farmasi adalah obat, bahan obat, obat tradisional dan kosmetika (Nomor, 72AD). Terkait obat keras, yang diatur dalam PP Farmasi adalah bahwa dalam melakukan Pekerjaan Kefarmasian pada Fasilitas Pelayanan Kefarmasian, Apoteker dapat menyerahkan obat kepada masyarakat atas resep dari dokter sesuai dengan ketentuan peraturan perundang-undangan (Indonesia, 2009). Selain itu menurut pasal 1 mengenai ketentuan umum dari Peraturan Pemerintah Nomor 51 Tahun 2009 disebutkan bahwa "Apotek adalah sarana pelayanan kefarmasian tempat dilakukan praktek kefarmasian oleh Apoteker" (Pemerintah, 2009). Peredaran menurut Peraturan 
Pemerintah Nomor 72 Tahun 1998 tentang Pengamanan Sediaan Farmasi dan Alat Kesehatan Pasal 1 angka 4;

"Peredaran adalah setiap kegiatan atau serangkaian kegiatan penyaluran atau penyerahan sediaan farmasi dan alat kesehatan baik dalam rangka perdagangan, bukan perdagangan, atau pemindah tanganan " (Nomor, 72AD).

Memang penyerahan sediaan farmasi itu sendiri terbagi menjadi 2 yaitu melalui resep dokter dan tanpa resep dokter, (Nomor, 72AD) namun masyarakat seringkali dihadapkan kepada fenomena tentang peredaran obat yang masuk dalam katagori untuk mendapatkannya harus dengan resep dokter tetapi beberapa toko obat bahkan apotek menjualnya secara bebas. Dalam penulisan penelitian ini penulis mengambil studi kasus pelanggaran pengedaran obat keras tanpa resep dari dokter dan diperjualbelikan diluar Apotek yang perkaranya sudah ditangani oleh Pengadilan Negeri Cibinong dengan Putusan Nomor: 59/Pid.Sus/2018/PN.Cbi. Dalam kasus ini terdakwa Zaenal Abidin Bin Basyah (Alm), yang dalam persidangan berdasarkan fakta-fakta yang terungkap bukti bahwa Terdakwa Zaenal Abidin Bin Basyah (Alm) didakwa telah memiliki dan mengedarkan obat sediaan farmasi berbentuk obat keras dengan dakwaan yaitu Pasal 196 UU. RI No.36 tahun 2009 tentang Kesehatan. Dalam kasus ini Zaenal Abidin Bin Basyah (Alm) oleh karena itu dipidana penjara selama 1 (satu) tahun dan 4 (empat) bulan dan denda sejumlah Rp. 10.000.000 (sepuluh juta rupiah).

\section{Metode Penelitian}

Penelitian yang di gunakan dalam penelitian ini adalah yuridis normative, yaitu menganalisis kaitan antara peraturan perundang-undangan yang berlaku dengan teoriteori hukum dan praktek pelaksanaan hukum positif yang menyangkut permasalahan yang dibahas. Penelitian ini akan menganalisis masalah hukum, fakta, dan gejala hukum lainnya yang berkaitan dengan pendekatan hukum, kemudian di peroleh gambaran yang menyeluruh mengenai masalah yang akan di teliti penelitian yang berbentuk deskriptif analisis ini hanya akan menggambarkan keadaan objek atau persoalan dan tidak dimaksudkan mengambil atau menarik kesimpulan yang berlaku umum mengenai tanggungjawab hukum pelaku pelanggaran pengedaran obat keras (Soekanto, 2014).

Penelitian ini meliputi penelitian mengenai ketentuan hukum positif yang berlaku di Indonesia yang berkaitan tanggungjawab hukum pelaku pelanggaran pengedaran obat keras. Penelitian dengan yuridis normatif ini lebih menitik beratkan kepada studi kepustakaan, baik bahan hukum primer, sekunder dan bahan hukum hukum tertier yaitu berupa:

a. Bahan Hukum Primer

1) Undang-Undang No 23 tahun 1992 Tentang Kesehatan ;

2) Undang-Undang No. 36 tahun 2009 Tentang Kesehatan ;

3) Peraturan Pemerintah Nomor 51 Tahun 2009 tentang Pekerjaan Kefarmasian ;

4) Peraturan Pemerintah Nomor 72 Tahun 1998

5) Peraturan Menteri Kesehatan Nomor 917/Menkes/Per/X/1993 tentang Wajib Daftar Obat Jadi ; 
6) Keputusan Menteri Kesehatan Republik Indonesia Nomor 386/Menkes/SK/IV/1994 tentang Pedoman Periklanan Obat Bebas,

b. Bahan Hukum Sekunder

Bahan-bahan yang memberikan penjelasan mengenai bahan hukum primer dan implementasinya, seperti hasil-hasil penelitian, hasil karya dari kalangan hukum, makalah-makalah seminar, dan lain-lain. Dalam penelitian dan penulisan penelitian ini meliputi bahan-bahan bacaan yang ada hubungannya dengan tanggungjawab hukum pelaku pelanggaran pengedaran obat keras, sebagai objek yang teliti yaitu literatur dan karya ilmiah yang berkaitan dengan masalah yang akan di teliti.

c. Bahan Hukum Tersier

Bahan hukum yang memberikan penjelasan lebih lanjut dari bahan hukum primer dan sekunder yaitu, kamus, baik kamus terjemahan maupun kamus hukum, majalah dan internet (virtual research) (Soekanto, 1986).

\section{Hasil dan Pembahasan}

A. Pengaturan Hukum Pidana Materiil Terhadap Perkara Pidana Pemilikan Dan Pengedaran Obat Keras Tanpa Resep Dokter Putusan Pengadilan Nomor: 59/Pid.Sus/2018/PN.Cbi

Berdasarkan Penjelasan Undang-Undang Republik Indonesia Nomor 36 Tahun 2009 tentang Kesehatan, Pasal 2 telah dijelaskan dan dinyatakan bahwa pembangunan kesehatan harus memperhatikan berbagai asas yang memberikan arah pembangunan kesehatan. Asas-asas tersebut dilaksanakan melalui upaya kesehatan, sebagai berikut (Hendrik, 2011):

1. Asas perikemanusiaan yang berarti bahwa pembangunan kesehatan harus dilandasi atas prikemanusiaan yang berdasarkan pada Ketuhanan Yang Maha Esa dengan tidak membedakan golongan, agama, dan bangsa.

2. Asas keseimbangan berarti bahwa pembangunan kesehatan harus dilaksanakan antara kepentingan indiviu dan masyarakat, antara fisik dan mental serta antara material dan spiritual.

3. Asas manfaat berarti bahwa pembangunan kesehatan harus memberikan manfaat yang sebesar-besarnya bagi kemanusiaan dan prikehidupan yang sehat bagi setiap warga negara.

4. Asas perlindungan berarti bahwa pembangunan kesehatan harus dapat memberikan perlindungan dan kepastian hukum kepada pemberi dan penerima pelayanan kesehatan.

5. Asas penghormatan terhadap hak dan kewajiban berarti bahwa pembangunan kesehatan dengan menghormati hak dan kewajiban masyarakat sebagai bentuk kesamaan kedudukan hukum.

6. Asas keadilan berarti bahwa penyelenggaraan kesehatan harus dapat memberikan pelayanan yang adil dan merata kepada semua lapisan masyarakat dengan pembiayaan yang terjangkau. 
7. Asas gender dan non diskriminatif berarti bahwa pembangunan kesehatan tidak membedakan perlakuan terhadap perempuan dan laki-laki.

8. Asas norma agama berarti pembangunan kesehatan harus memperhatikan dan menghormati serta tidak membedakan agama yang dianut masyarakat.

Pengaturan mengenai pengamanan dan penggunaan sediaan farmasi di Indonesia diatur di dalam Undang-Undang Republik Indonesia Nomor 36 Tahun 2009 Tentang Kesehatan Pasal 108 ayat (1) dan (2). Adapun dalam hal ini hak pasien tertera dalam Pasal 8 Undang-Undang No. 8 tahun 1999 tentang Perlindungan Konsumen salah satu larangan bagi pelaku usaha (tenaga kesehatan) dalam menjalankan kegiatan usahanya adalah (Abdul R Saliman, 2005):

1. Tidak memenuhi atau tidak sesuai dengan standar yang dipersyaratkan dari ketentuan perundang-undangan.

2. Tidak sesuai dengan berat bersih, isi bersih atau netto, dan jumlah dalam hitungan sebagaimana dinyatakan dalam label atau etiket barang tersebut.

3. Tidak sesuai dengan ukuran, takaran, timbangan, dan jumlah dalam hitungan menurut ukuran yang sebenarnya.

4. Tidak sesuai dengan kondisi, jaminan, keistimewaan, atau kemanjuran sebagaimana dinyatakan dalam label, etiket, atau keterangan barang dan/ jasa tersebut.

5. Tidak sesuai dengan mutu, tingkatan, komposisi, proses pengolahan, gaya, mode, atau penggunaan tertentu sebagaimana dinyatakan dalam label, etiket, atau keterangan barang dan/atau jasa tersebut.

6. Tidak sesuai dengan janji yang dinyatakan dalam label, etiket, keterangan, iklan, atau promosi barang dan/atau jasa tersebut.

7. Tidak mencantumkan tanggal kadaluarsa atau jangka waktu penggunaan/pemanfaatan yang paling baik atas barang tertentu. Jangka waktu penggunaan/pemanfaatan nya yang paling baik adalah terjemahan dari kata "best before" yang biasanya digunakan dalam label produk makanan.

8. Tak mengikuti ketentuan berproduksi secara halal, sebagaimana dinyatakan "halal" yang dicantumkan dalam label.

9. Tidak memasang label atau membuat penjelasan barang yang memuat nama barang, ukuran, berat/isi bersih atau neto, komposisi, aturan pakai, tanggal pembuatan, akibat sampingan, nama, dan alamat pelaku usaha, serta keterangan lain untuk penggunaan yang menurut ketentuan harus dipasang atau dibuat.

10. Tidak mencantumkan informasi dan/atau petunjuk penggunaan barang dalam bahasa Indonesia sesuai dengan ketentuan perundang-undangan yang berlaku.

11. Memperdagangkan barang yang rusak, cacat atau bekas, dan tercemar tanpa memberikan informasi yang lengkap.

12. Memperdagangkan sediaan farmasi dan pangan yang rusak, cacat atau bekas, dan tercemar, dengan atau tanpa memberikan informasi secara lengkap.

Berbagai jenis pengobatan tidak selamanya bersifat menyembuhkan, bahkan tidak jarang bila menggunakan obat-obatan yang tidak sesuai justru akan 
menimbulkan penyakit yang baru (Wibowo, 2012). Karena hal tersebut dan sangat pentingnya fungsi obat, banyak masyarakat yang menyalahgunakan. Misalnya masyarakat yang dengan sengaja mengedarkan obat-obatan diluar fasilitas pelayanan kefarmasian serta tidak memiliki keahlian dan kewenangan yang telah ditetapkan oleh peraturan perundang-undangan.

Salah satu contoh kasus pengedaran obat keras atau tertentu yang seharusnya dengan resep dokter tapi karena ulah oknum tertentu yang ingin mengambil keuntungan pribadi, obat keras dapat beredar dengan bebas, sehingga hal tersebut dapat dikatagorikan sebagai pelanggaran atau bahkan sebagai tindak pidana sebagaimana penulis contohkan dalam Putusan Pengadilan negeri Cibinong Nomor : 59/Pid.Sus/2018/PN.Cbi, yang pelakunya dihukum dengan pidana penjara selama 1 (satu) tahun dan 4 (empat) bulan dan denda sejumlah Rp. 10.000 .000 (sepuluh juta rupiah).

Semakin maraknya peredaran obat ilegal yang salah satu contohnya yaitu peredaran sediaan farmasi yang seharusnya dengan resep dokter malah dapat dibeli bebas tanpa resep dokter bahkan seringkali kita temukan di salah satu fasilitas pelayanan kefarmasian contoh apotek. Hal ini membuktikan bahwa masih lemahnya pertahanan Indonesia dari serbuan hal-hal yang membahayakan masyarakat. Membiarkan beredarnya obat keras secara ilegal sama saja dengan membiarkan masyarakat menghadapi berbagai risiko buruk, membiarkan kejahatan berkembang di masyarakat, dan merendahkan kepercayaan, martabat, serta harga diri bangsa di mata dunia internasional. Hal ini terjadi juga karena faktor yang berhubungan dengan adanya kesempatan terjadinya kriminalitas baik pelanggaran-pelanggaran kecil maupun besar (Soerjono Soekanto, 2019).

\section{B. Sanksi Hukum Tindak Pidana Peredaran Sediaan Farmasi Tanpa Resep Dokter}

Setiap hubungan hukum pasti mempunyai 2 (dua) sisi hak dan kewajiban. Hak dan kewajiban harus dibedakan dengan hukum karena hak dan kewajiban mempunyai sifat individual, melekat pada individu, sedangkan hukum bersifat umum, berlaku pada setiap orang. Hak pasien dapat muncul dari hubungan hukum antara tenaga kesehatan dan pasien dan muncul dari kewajiban profesional tenaga kesehatan berdasarkan ketentuan-ketentuan profesi. Menurut Fred Ameln hak pasien meliputi hak atas informasi, hak memilih sarana kesehatan, hak atas rahasia kedokteran, hak menolak pengobatan, hak menolak suatu tindakan medik tertentu, hak untuk menghentikan pengobatan, hak melihat rekam medis, hak second opinion. Tanggung jawab hukum tenaga kesehatan dimaksudkan sebagai keterkaitan seorang tenaga kesehatan terhadap ketentuan-ketentuan hukum dalam menjalankan profesinya. Tanggung jawab hukum tersebut meliputi (Hendrik, 2011):

1. Bidang hukum pidana, Undang-Undang Nomor 36 Tahun 2009, Pasal 190-200 dan pasal-pasal dalam Kitab Undang-Undang Hukum Pidana seperti Pasal 224, 267-268, 322, 344-350, 531 dan pasal 535. 
2. Bidang hukum perdata, khususnya mengenai ketentuan-ketentuan pada buku III Kitab Undang-Undang Hukum Perdata tentang perikatan dan Pasal 58 UndangUndang Nomor 36. Tahun 2009 tentang Kesehatan.

Sehubungan dengan tanggung jawab hukum tenaga kesehatan di bidang hukum perdata ini, ada 2 (dua) bentuk pertanggungjawaban tenaga kesehatan yang pokok yaitu Pertanggungjawaban atas kerugian yang disebabkan karena wanperstasi dan pertanggungjawaban atas kerugian yang disebabkan karena melawan hukum. Pada dasarnya pertanggungjawaban perdata bertujuan untuk memperoleh kompensasi atas kerugian yang diderita selain untuk mencegah terjadinya hal-hal yang tidak diinginkan. Karena itu baik wanprestasi maupun perbuatan melawan hukum merupakan dasar untuk menuntut tanggung jawab tenaga kesehatan.

Ketentuan mengenai tindak pidana mengedarkan sediaan farmasi diatur dalam Undang-Undang Nomor 36 Tahun 2009 tentang Kesehatan Pasal 196, rumusan yang terdapat dalam pasal ini adalah : "Setiap orang yang dengan sengaja memproduksi atau mengedarkan sediaan farmasi dan/atau alat kesehatan yang tidak memenuhi standar dan/atau persyaratan keamanan,khasiat atau kemanfaatan, dan mutu sebagaimana dimaksud dalam pasal 98 ayat (2) dan ayat (3) dipidana dengan pidana penjara paling lama 10 (sepuluh) tahun dan denda paling banyak Rp.1.000.000.000 (satu miliar rupiah)".

Sedangkan Undang-Undang Kesehatan Undang-Undang Nomor 36 Tahun 2009 tentang Kesehatan Pasal 98:

1. Sediaan farmasi dan alat kesehatan harus aman, berkhasiat/bermanfaat, bermutu, dan terjangkau.

2. Setiap orang yang tidak memiliki keahlian dan kewenangan dilarang mengadakan, menyimpan, mengolah, mempromosikan, dan mengedarkan obat dan bahan yang berkhasiat obat.

3. Ketentuan mengenai pengadaan, penyimpanan, pengolahan, promosi, peredaran sediaan farmasi dan alat kesehatan harus memenuhi standar mutu pelayanan farmasi yang ditetapkan dengan Peraturan Pemerintah

4. Pemerintah berkewajiban membina, mengatur, mengendalikan, dan mengawasi pengadaan, penyimpanan, promosi, dan pengedaran sebagaimana dimaksud pada ayat (3).

Namun demikian masih begitu banyak masyarakat yang masih saja mengedarkan obat-obatan yang seharusnya melalui resep dokter, tetapi diperjualbelikan secara bebas. Masalah ini merupakan masalah serius yang terjadi dimasyarakat luas, kurangnya informasi terhadap obat-obatan serta minimnya informasi tentang akibat-akibat yang ditimbulkan karena adanya peredaran obat keras dan sanksi yang mereka terima apabila mengedarkan obat keras tanpa resep dokter tersebut juga mempengaruhi tindakan ini.

Menurut pendapat penulis, pengaturan tentang Peredaran Obat sudah mendapat pengaturan yang lengkap, diantaranya adalah sudah diberlakukannya Undang Undang Republik Indonesia Nomor 36 Tahun 2009 Tentang Kesehatan, 
Peraturan Pemerintah Republik Indonesia Nomor 51 Tahun 2009 tentang Pekerjaan Kefarmasian, serta Keputusan Menteri Kesehatan Nomor 20396/A/SK/VIII/86 tentang Tanda Khusus Obat Keras Daftar G. Dalam Perkara Tindak Pidana Nomor 59/Pid.Sus.2018/PN.Cbi telah diproses dan ditangani perkara hukumnya oleh aparat penegak hukum sesuai dengan pengaturan peundang-undangan yang berlaku sebagai hukum positif di Negara Indonesia, yaitu dengan melalui proses penyidikan, proses penuntutan, dan proses persidangan di pengadilan negeri sebagaimana kompetensi relatif maupun kompetensi absolut kewenangan pengadilan didalam menangani dan memutus suatu perkara.

\section{Pertimbangan Hukum Hakim Dalam Perkara Pidana Nomor 59/Pid.Sus/2018/Pn.Cbi}

\section{Posisi Kasus:}

a) Bahwa pada hari Rabu, tanggal 20 September 2017, sekira jam 17.00 wib, bertempat di tepi jalan Raya Taman Pagelaran Ciomas, Kec. Ciomas, Kabupaten Bogor, terdakwa ditangkap oleh saksi yang saat itu sedang melakukan piket dikantor Polres

b) Bahwa saksi Noerman dan saksi Brigadir Danny Setiawan mendatangi lokasi dan melihat terdakwa sedang menjaga toko milik sdr. Muzakir (belum tertangkap) yang menjual obat-obatan dan ditemukan serta disita Tramadol Polos sebanyak 6 (enam) butir, Hexymer sebanyak 20 (dua puluh) butir,10 (sepuluh) butir/1 strip Tramadol HCL, Trihexypheridyl sebanyak 5 (lima) butir yang semua nya disimpan dalam toko yang dijaga terdakwa setelah sebelumnya mendapat informasi telpon dari masyarakat ;

c) Bahwa terdakwa dalam hal ini sengaja memproduksi atau mengedarkan sediaan farmasi dan/atau alat kesehatan yang tidak memenuhi standar dan/atau persyaratan keamanan, khasiat atau kemanfaatan dan mutu.

d) Bahwa terdakwa dihadapkan ke persidangan telah didakwa dengan dakwaan alternatif yaitu dakwaan Kesatu Pasal 196 UU RI No. 36 Tahun 2009 tentang Kesehatan atau dakwaan Kedua Pasal 197 UU RI No. 36 Tahun 2009 tentang Kesehatan.

e) Bahwa berdasarkan uraian fakta dan pertimbangan sebagaimana terurai, maka Majelis Hakim berpendapat bahwa perbuatan terdakwa menjual, mengedarkan, menyimpan, membawa, memiliki, menguasai, menyediakan atau menyerahkan obat-obatan yaitu jenis Tramadol Polos, Hexymer, Tramadol HCL dan Trihexipheridyl tanpa dilengkapi dengan surat izin dari Departemen Kesehatan Republik Indonesia atau instansi terkait lainnya merupakan perbuatan yang dilarang oleh undang-undang.

\section{Fakta Persidangan}

a) Bahwa dalam persidangan, majelis hakim tidak menemukan hal-hal yang dapat menghapus pertanggungjawaban pidana, baik sebagai alasan pembenar dan atau alasan pemaaf, maka terdakwa harus mempertanggungjawabkan perbuatannya; 
b) Bahwa dalam perkara ini terhadap terdakwa telah dikenakan penangkapan dan penahanan terhadap terdakwa tetap berada dalam tahanan;

c) Bahwa oleh karena terdakwa ditahan dan penahanan terhadap terdakwa dilandasi alasan yang cukup, maka perlu ditetapkan agar terdakwa tetap berada dalam tahanan;

d) Bahwa barang bukti berupa pecahan uang Rp. 5.000 (lima ribu rupiah); sebanyak 10 (sepuluh) lembar yang merupakan hasil dari kejahatan serta mempunyai nilai ekonomis, maka perlu ditetapkan agar barang bukti tersebut dirampas untuk negara;

e) Bahwa barang bukti berupa Tramadol Polos 6 butir, Hexymer 20 butir, Tramadol HCL 10 butir/1 strip, Trihexipheridyl 5 butir, yang telah dipergunakan untuk melakukan kejahatan dan dikhawatirkan akan dipergunakan untuk mengulangi kejahatan, maka perlu ditetapkan agar barang bukti tersebut dimusnahkan sehingga tidak dapat dipergunakan lagi;

\section{Pertimbangan Hakim}

Dengan memperhatikan fakta-fakta hukum tersebut diatas memilih langsung dakwaan alternatif Kesatu sebagaimana diatur dalam Pasal 196 UU RI No. 36 Tahun 2009 tentang Kesehatan tersebut, bila diurakan unsurnya adalah sebagai berikut:

\section{1) Unsur Setiap orang;}

a) Menimbang, bahwa unsur setiap orang diartikan setiap orang laki-laki maupun perempuan yang dihadapkan dimuka persidangan sebagai subjek hukum yang mempunyai jasmani dan rohani sehat dan dapat dipertanggungjawabkan secara hukum;

b) Menimbang, bahwa Terdakwa yang bernama Zaenal Abidin Bin Basyah (Alm) dengan segala identitasnya yang tersebut dalam surat dakwaan dan diawal surat tuntutan ini, yang pada awal persidangan identitas tersebut telah diteliti dengan seksama oleh majelis hakim dimana identitas tersebut telah dibenarkan pula oleh terdakwa sebagai identitas jati dirinya, selanjutnya tentu saja yang dimaksud orang adalah orang yang dapat atau mampu mempertanggungjawabkan setiap perbuatan atau tindakannya, dimana secara objektif terdakwa Zaenal Abidin Bin Basyah (Alm) dipersidangan telah menunjukkan kecakapan dan kemampuan dimana terdakwa dalam keberadaannya secara objektif mempunyai fisik dan psikis yang sehat dan memadai dan tidak terbukti adanya halangan untuk dapat mempertanggungjawabkannya secara hukum;

2) Unsur yang dengan sengaja melawan hukum mengedarkan sediaan farmasi dan/atau alat kesehatan yang tidak memenuhi standar dan/atau persyaratan keamanan, khasiat atau kemanfaatan dan mutu.

a) Bahwa yang dimaksud "Dengan sengaja" adalah suatu perbuatan itu telah dilakukan dengan disadari atau telah ada niat dari pelaku, baik untuk 
melakukan perbuatan itu sendiri ataupun timbulnya suatu akibat dari perbuatan yang akan dilakukannya itu;

b) Bahwa yang dimaksud dengan "sediaan farmasi" menurut pasal 1 ayat (4) Undang - undang Nomor 36 tahun 2009 tentang kesehatan adalah obat, bahan obat,obat traditional dan kosmetika;

c) Berdasarkan faka-fakta yang terungkap dalam persidangan dari keterangan saksi-saksi, Ahli dan keterangan terdakwa pada hari Rabu tanggal 20 September 2017,sekitar jam : 17.00 Wib, di Jalan Raya Taman Pagelaran Ciomas, Kecamatan Ciomas, Kabupaten Bogor, Terdakwa dilakukan penangkapan kemudian pihak Kepolisian melakukan penggeledahan ditemukan barang bukti berupa : Tramadol Polos 6 butir, Hexymer 20 butir, Tramadol HCL 10 butir/1 strip, Trihexipheridyl 5 butir semuanya disimpan atau ditemukan didalam etalase toko tempat terdakwa berjualan.

d) Bahwa obat-obatan yaitu berupa Tramadol Polos 6 butir, Hexymer 20 butir, Tramadol HCL 10 butir/1 strip, Trihexipheridyl 5 butir yang diduga sediaan farmasi jenis obat kesehatan yang disimpan atau ditemukan didalam kios yang terdakwa jaga tersebut yaitu milik sdr. Muzakir dan adapun saya hanya sebagai penjaga atau pelayan toko yang disuruh sdr. Muzakir untuk menjaga, menjualatau mengedarkan sediaan farmasi jenis obat kesehatan tersebut dan terdakwa disuruh sdr. Muzakir untuk menjualnya dengan harga untuk Tramadol Polos 3 butir seharga Rp. 5.000 (lima ribu rupiah), Hexymer 10 butir seharga Rp. 10.000 (sepuluh ribu rupiah), Tramadol HCL 1 strip seharga Rp. 20.000 (dua puluh ribu rupiah), Trihexipheridyl 5 butir seharga Rp. 5.000 (lima ribu rupiah) kepada pembeli atau konsumen;

Berdasarkan fakta hukum sebagaimana diuraikan diatas maka majelis hakim menilai bahwasanya perbuatan terdakwa menjual, mengedarkan, menyimpan, membawa, memiliki, menguasai, menyediakan, atau menyerahkan obat-obatan yaitu jenis Tramadol Polos, Hexymer, Tramadol HCL, Trihexipheridyl tanpa dilengkapi dengan surat izin dari Departemen Kesehatan RI atau Instansi terkait lainnya merupakan perbuatan yang dilarang undangundang. Bahwa dengan demikian unsur "dengan sengaja melawan hukum mengedarkan sediaan farmasi dan/atau alat kesehatan yang tidak memenuhi standar dan/atau persyaratan keamanan, khasiat atau kemanfaatan dan mutu" telah terpenuhi.

\section{Putusan Hakim}

Memperhatikan, Pasal 196 Undang-undang Nomor 36 tahun 2009 tentang Kesehatan dan Undang-undang Nomor 8 tahun 1981 tentang Hukum Acara Pidana serta peraturan perundang-undangan lain yang bersangkutan. Majelis Hakim menetapkan putusan sebagai berikut: 
a) Menyatakan terdakwa Zaenal Abidin Bin Basyah (Alm) telah terbukti secara sah dan meyakinkan bersalah melakukan tindak pidana "dengan sengaja mengedarkan sediaan farmasi dan/atau alat kesehatan yang tidak memenuhi standar dan/atau persyaratan keamanan, khasiat atau kemanfaatan dan mutu"

b) Menjatuhkan pidana kepada terdakwa Zaenal Abidin Bin Basyah (Alm) oleh karena itu dengan pidana penjara selama 1 (satu) tahun dan 4 (empat) bulan dan denda sejumlah Rp. 10.000.000 (sepuluh juta rupiah) dengan ketentuan apabila denda tersebut tidak dibayar diganti dengan pidana kurungan selama 2 (dua) bulan;

c) Menetapkan masa penangkapan dan penahanan yang telah dijalani oleh terdakwa dikurangkan seluruhnya dari pidana yang dijatuhkan.

Jika diteliti lebih dalam dari pertimbangan hukum hakim dalam memutuskan perkara nomor 59/Pid.Sus/2018/PN. Cbi apakah sudah memenuhi aspek keadilan? Dalam perkara tersebut hakim memutuskan bahwa terdakwa Zaenal Abidin Bin Basyah telah terbukti secara sah dan meyakinkan bersalah melakukan tindak pidana "dengan sengaja mengedarkan sediaan farmasi dan/atau alat kesehatan yang tidak memenuhi standard an/atau persyaratan keamanan, khasiat atau kemanfaatan dan mutu“. Sesuai dengan dakwaan kesatu dari penuntut umum seperti dimaksud dalam pasal 196 Undang-Undang Nomor 36 Tahun 2009 tentang Kesehatan. Mengenai kesalahan terdakwa, yaitu terdakwa bukan merupakan orang yang memiliki keahlian dan kewenangan dalam mengadakan, menyimpan, mengolah, mempromosikan, dan mengedarkan obat dan bahan yang berkhasiat obat, sesuai dengan pasal 98 ayat (2) Undang-Undang Kesehatan.

Sudah dijelaskan dalam kronologis perkara bahwa terdakwa adalah bukan pemilik toko, karena pemilik toko sampai saat ini belum tertangkap, terdakwa hanyalah seorang pekerja yang hanya disuruh menjaga toko dan menjual serta mendapat gaji Rp. 500.000,00 (lima ratus ribu rupiah). Kesimpulan yang didapat adalah terdakwa tidak mengerti sama sekali peraturan perundang-undangan yang berlaku mengenai pemilikan dan peredaran sediaan farmasi atau alat kesehatan terutama obat keras dimana seharusnya obat keras harus diperjualbelikan melalui resep dokter serta harus diserahkan oleh apoteker.

Adapun menurut penulis hal-hal yang harus dipertimbangkan lagi oleh hakim disamping pertimbangan-pertimbangan yang ada, sebelum menjatuhkan vonis Majelis Hakim juga harus mempertimbangkan beberapa hal penting sebagai berikut ;

a) Terdakwa bukan merupakan pelaku utama, dan juga tidak memperoleh keuntungan dalam perbuatannya, karena posisi terdakwa hanyalah seorang yang bekerja dengan upah sebesar Rp.500.000,- per bulan.

b) Keberadaan Terdakwa dalam hal ini hanya sebagai pekerja yang menjalankan perintah dari pemilik toko sebagai majikannya. 
c) Pekerja baru bekerja 3 (tiga) bulan dan selama 3 bulan baru mendapatkan upah Rp.1.500.000,-

d) Tidak ada korban jiwa yang dapat dibuktikan karena perbuatan terdakwa.

Mengenai pertimbangan di atas penulis berpendapat bahwa seharus nya terdakwa tidak tepat dijadikan tersangka, karena peran tersangka hanya sebagai pekerja yang menjalankan perintah dari pemilik toko atau majikan. Terhadapnya akan lebih tepat jika dijadikan sebagai saksi dalam kasus tersebut yang dapat diminta keterangannya sputar keberadaan tersangka dan kegiatan-kegiatan yang dilakukan ditoko tersebut yang semuanya dikelola dan dikendalikan oleh pemilik toko atau majikan.

Penulis juga berpendapat, apabila terdakwa tetap harus dijerat dalam kasus ini, akan lebih tepat jika Majelis Hakim memberikan keputusan berupa vonis hukuman percobaan kepada Terdakwa, karena vonis penjara sangat tidak sepadan dengan perbuatan yang dilakukan oleh terdakwa bahkan terdakwa pun tidak memperoleh keuntungan dari kegiatan tersebut. Berdasarkan uraian di atas jika Majelis Hakim mengadili terdakwa dengan hukuman penjara, penulis berpendapat bahwa pertimbangan-pertimbangan Majelis Hakim tidak memenuhi aspek keadilan. Akan lebih tepat jika Majelis Hakim mengadili terdakwa dengan Hukuman Bersyarat atau lebih dikenal dengan Hukuman Percobaan.

\section{Kesimpulan}

Peraturan Perundang-undangan telah mengatur bagaimana jalur pengedaran obat keras yaitu: a). Haruslah melalui resep dokter. b). Melalui fasilitas pelayanan kefarmasian yang ditentukan undang-undang. c). Penyerahan dan pelayanan harus melalui tenaga teknis kefarmasian dalam hal ini adalah apoteker.

Memperjual belikan obat keras dapat dikenai sanksi pidana yaitu Pasal 196 Undang-Undang Nomor 36 Tahun 2009 tentang kesehatan, bahwa : Setiap orang yang dengan sengaja memproduksi atau mengedarkan sediaan farmasi dan/atau alat kesehatan yang tidak memenuhi standard dan/atau persyaratan keamanan, khasiat atau kemanfaatan, dan mutu sebagaimana dimaksud dalam Pasal 98 ayat (2) dan ayat (3) dipidana dengan pidana penjara paling lama 10 (Sepuluh) Tahun Dan Denda Paling Banyak Rp.1.000.000.000 (Satu Miliar Rupiah).

1. Dalam Putusan Pengadilan Nomor 59/Pid.Sus/2018/PN. Cbi terdakwa Zaenal Abidin Bin Basyah (Alm) telah dipidana penjara selama 1 (satu) tahun dan 4 (empat) bulan dan denda sejumlah Rp. 10.000 .000 (sepuluh juta rupiah) akan tetapi putusan hakim haruslah mempunyai tujuan sebagai:

a. kepastian hukum

b. kemanfaatan

c. Keadilan

Dalam memutuskan vonis hendaknya hakim lebih jeli dalam memeriksa sebuah perkara. Suatu putusan pengadilan yang berkualitas, adalah putusan yang dapat dipertanggungjawabkan bukan saja dari sisi dan aspek kepastian hukum 
Pertimbangan Hukum Hakim Terhadap Pemilikan dan Pengedaran Obat Keras Tanpa Resep Dokter

(rumusan pasal-pasal dalam undang-undang) dan kemanfaatan bagi para pihak semata tetapi juga mencerminkan keadilan dan nilai-nilai kemanusiaan. Dalam putusan perkara nomor 59/Pid.Sus/2018/PN. Cbi menurut penulis sebaiknya putusan hakim hanya hukuman pidana bersyarat atau percobaan serta bukan hukuman penjara dan denda dikarenakan:

a. Terdakwa bukan lah pelaku utama

b. Terdakwa hanyalah seorang pekerja dan baru bekerja selama 3 bulan

c. Belum ada korban

Oleh sebab itu penulis berpendapat bahwa aspek keadilan dari putusan hakim dengan nomor perkara 59/Pid.Sus/2018/PN. Cbi tidak berjalan sebagaimana mestinya. 


\section{BIBLIOGRAFI}

Abdul R Saliman, Dkk. (2005). Hukum Bisnis Untuk Perusahaan. Jakarta: Pranada Media Grup.

Anief, Moh. (1997). Apa yang perlu diketahui tentang obat. Gadjah Mada University Press. Google Scholar

Atmoko, Widi, \& Kurniawati, I. (2009). Swamedikasi: Sebuah respon realistik perilaku konsumen di masa krisis. Bisnis Dan Kewirausahaan, 2(3), 233-247. Google Scholar

Daud, L. I. A. Rizky Amalia. (2016). Implementasi Pasal 196 Undang-Undang Nomor 36 Tahun 2009 Tentang Kesehatan Terhadap Pelaku Peredaran Obat Batuk Yang Mengandung Dextromethorphan Tunggal. Skripsi, 1(271412016). Google Scholar

DepKes, R. I. (2006). Pedoman penggunaan obat bebas dan bebas terbatas. Jakarta, Direktorat Bina Farmasi Komunitas Dan Klinik, Ditjen Bina Kefarmasian Dan Alat Kesehatan, Departemen Kesehatan RI.

Hendrik. (2011). Etika \& Hukum Kesehatan. Jakarta: EGC.

Indonesia, Presiden Republik. (2009). Peraturan Pemerintah Republik Indonesia Nomor 51 Tahun 2009 tentang Pekerjaan Kefarmasian.

Meitasari, Meitasari. (2017). Perilaku Seksual Remaja Pengguna Smartphone (Studi Kasus Di Ma Raudlatul Hidayah Ma'arif $\mathrm{Nu} 03$ Lampung Timur). Jurnal Bimbingan Dan Konseling Ar-Rahman, 3(1), 1-5. Google Scholar

Nomor, Peraturan Pemerintah Republik Indonesia. (72AD). Tahun 1998 tentang Pengamanan sediaan farmasi dan alat kesehatan. Pasal.

Oh, Rita Sri Hastuti. (2016). Pelaksanaan Pekerjaan Kefarmasian Dalam Pelayanan Kefarmasian Di Rumah Sakit Kota Semarang Setelah Berlakunya Undang-Undang Nomor 36 Tahun 2014 Tentang Tenaga Kesehatan. Unika Soegijapranata. Google Scholar

Pemerintah, R. I. (2009). Peraturan Pemerintah No. 51 tentang Pekerjaan Kefarmasian. Jakarta.

Soekanto, Soerjono. (1986). Pengantar Penelitian Hukum, UI. Press, Jakarta. Google Scholar

Soekanto, Soerjono. (2014). Sosiologi suatu pengantar. Google Scholar

Soerjono Soekanto. (2019). Pengantar Penelitian Hukum. Jakarta: UI Press.

Wibowo, Teguh. (2012). 100 Ramuan Herbal Warisan Leluhur. Jogjakarta, Ozura. 
Pertimbangan Hukum Hakim Terhadap Pemilikan dan Pengedaran Obat Keras Tanpa Resep Dokter

Google Scholar

\section{Copyright holder:}

Stevanus Miharso (2021)

First publication right:

Syntax Literate: Jurnal Ilmiah Indonesia

This article is licensed under:

(c) $\underset{\mathrm{EY}}{(\mathrm{i})} \mathrm{Pa}$ 